Supporting Information

\title{
Dissecting Sesquiterpene Profiles of Lemberger Red Wines Using Ex Vivo Tissue Deuterium-Labeling and Comprehensive Two-Dimen- sional Gas Chromatography-Time-of-Flight-Mass Spectrometry
}

Philipp P. Könen, Matthias Wüst*

Chair of Food Chemistry, Institute of Nutritional and Food Sciences, University of Bonn, Endenicher Allee 19C, 53115 Bonn

\section{AUTHOR INFORMATION}

Corresponding Author

*Tel.: +49-228-73-2964. Fax: +49-228-73-3499. E-mail: matthias.wuest@ uni-bonn.de.

ORCID

Philipp P. Könen: 0000-0002-4847-7807

Matthias Wüst: 0000-0001-6808-5555 


\section{TABLE OF CONTENTS}

1. TABLES

Table S1. Authentic Lemberger red wines from the Hochschule Geisenheim University, which were analyzed in this study.

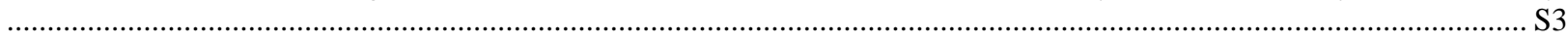

Table S2. Sesquiterpenes identified in headspace of an acidified, aqueous nerolidol solution...... S4

Table S3. Sesquiterpenes identified in headspace of a fermented aqueous approach consisting of a commercial yeast strain (Saccharomyces cerevisiae), yeast nutrients, D(+)-glucose and $\mathrm{D}(-)$-fructose.

Table S4. Pairs of genuine and deuterated sesquiterpene hydrocarbons after ex vivo tissue deuterium-labeling using $d_{3}$-MVL as the precursor, which were detected both before microvinification in the exocarp of Lemberger berries and after microvinification in Lemberger model wine. . S6

2. FIGURES S7

Figure S1. HS-SPME-GC $\times$ GC-TOF-MS analysis of an acidified, aqueous nerolidol solution (sample volume $1 \mathrm{~mL}$; concentration $1 \mathrm{mg} / \mathrm{L}$; acidified to $\mathrm{pH} 3.3$ using $\mathrm{L}(-)$-malic acid; preincubation temperature $30{ }^{\circ} \mathrm{C}$ ) to investigate the acidcatalyzed formation of sesquiterpenes. S7

Figure S2. Microvinification. S8

Figure S3. Headspace analysis of a fermented aqueous approach consisting of a commercial yeast strain (Saccharomyces cerevisiae), yeast nutrients, $\mathrm{D}(+)$-glucose and $\mathrm{D}(-)$-fructose. S9

Figure S4. MS spectra and expected labeling patterns of 8a: $d_{0}$ - $\alpha$-ylangene and $8 \mathrm{~b}: d_{8}-\alpha$-ylangene. .. S10

Figure S5. MS spectra and expected labeling patterns of 9a: $d_{0}$-guaia-6,9-diene and 9b: $d_{9}$-guaia-6,9-diene S11

Figure S6. MS spectra and expected labeling patterns of 10a: $d_{0}-\delta$-selinene and 10b: $d_{9}-\delta$-selinene. . S12

Figure S7. MS spectra and expected labeling patterns of $11 \mathrm{a}: d_{0}-\delta$-cadinene and $11 \mathrm{~b}: d_{8}-\delta$-cadinene S13

Figure S8. MS spectra and expected labeling patterns of 12a: $d_{0}$-selina-3,7(11)-diene and 12b: $d_{9}$-selina-3,7(11)-diene. S14

Figure S9. MS spectra and expected labeling patterns of 13a: $d_{0}$-calamenene (isomer) and $13 \mathrm{~b}$ : $d_{8}$-calamenene (isomer).

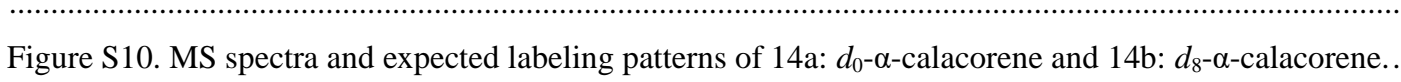

Figure S11. MS spectra and expected labeling patterns of $15 \mathrm{a}: d_{0}$ - $\alpha$-corocalene and $15 \mathrm{~b}: d_{8}$ - $\alpha$-corocalene.

Figure S12. MS spectra and expected labeling patterns of $16 \mathrm{a}: d_{0}$-cadalene and $16 \mathrm{~b}: d_{8}$-cadalene. S17

Figure S13. MS spectra and expected labeling patterns of $17 \mathrm{a}: d_{0}$-guaiazulene and 17b: $d_{9}$-guaiazulene. S18 


\section{TABLES}

Table S1. Authentic Lemberger red wines from the Hochschule Geisenheim University, which were analyzed in this study.

\begin{tabular}{lllll}
\hline Vintage & Harvest Day & $\begin{array}{l}\text { Soluble } \\
\text { Solids }\end{array}$ & $\begin{array}{l}\text { pH-Value } \\
\text { (Wine) }\end{array}$ & Alcohol Content \\
\hline 2009 & October 15, 2009 & $21.2^{\circ} \mathrm{Bx}$ & 3.40 & $106.0 \mathrm{~g} / \mathrm{L}$ \\
2010 & October 15, 2010 & $19.1^{\circ} \mathrm{Bx}$ & 3.50 & $108.7 \mathrm{~g} / \mathrm{L}$ \\
2011 & September 30, 2011 & $20.2^{\circ} \mathrm{Bx}$ & 3.50 & $101.7 \mathrm{~g} / \mathrm{L}$ \\
2012 & October 18, 2012 & $19.5^{\circ} \mathrm{Bx}$ & 3.30 & $111.1 \mathrm{~g} / \mathrm{L}$ \\
2013 & October 22, 2013 & $19.3{ }^{\circ} \mathrm{Bx}$ & 3.40 & $101.4 \mathrm{~g} / \mathrm{L}$ \\
2018 & September 14, 2018 & $18.6^{\circ} \mathrm{Bx}$ & 3.40 & $109.1 \mathrm{~g} / \mathrm{L}$ \\
\hline
\end{tabular}


Table S2. Sesquiterpenes identified in headspace of an acidified, aqueous nerolidol solution.

\begin{tabular}{|c|c|c|c|c|}
\hline Sesquiterpene $e^{[a]}$ & $\begin{array}{l}\text { Molecular } \\
\text { formula }\end{array}$ & $I^{[\mathrm{b}]}$ & $I(\text { lit. })^{[\mathrm{c}]}$ & Identification $^{[\mathrm{d}]}$ \\
\hline$\alpha$-cedrene (18) & $\mathrm{C}_{15} \mathrm{H}_{24}$ & 1590 & $1600^{1}$ & ms $(945,956)$, ri, std \\
\hline$\beta$-cedrene (19) & $\mathrm{C}_{15} \mathrm{H}_{24}$ & 1621 & $1630^{2}$ & ms $(892,905)$, ri \\
\hline$(E)-\beta$-farnesene (20) & $\mathrm{C}_{15} \mathrm{H}_{24}$ & 1668 & $1668^{3}$ & ms $(852,882)$, ri, std \\
\hline$\alpha$-zingiberene (21) & $\mathrm{C}_{15} \mathrm{H}_{24}$ & 1728 & $1721^{4}$ & ms $(835,845)$, ri \\
\hline$\beta$-bisabolene (22) & $\mathrm{C}_{15} \mathrm{H}_{24}$ & 1735 & $1729^{5}$ & ms $(890,895)$, ri \\
\hline$\alpha$-farnesene (23) & $\mathrm{C}_{15} \mathrm{H}_{24}$ & 1749 & $1749^{6}$ & ms $(900,922)$, ri, std \\
\hline$\beta$-curcumene (24) & $\mathrm{C}_{15} \mathrm{H}_{24}$ & 1750 & $1740^{7}$ & ms $(815,836)$, ri \\
\hline$\delta$-cadinene $(25)$ & $\mathrm{C}_{15} \mathrm{H}_{24}$ & 1771 & $1770^{8}$ & ms $(807,853)$, ri \\
\hline$\beta$-sesquiphellandrene (26) & $\mathrm{C}_{15} \mathrm{H}_{24}$ & 1779 & $1783^{9}$ & ms $(862,870)$, ri \\
\hline$(E)$ - $\alpha$-bisabolene $(\mathbf{2 7})$ & $\mathrm{C}_{15} \mathrm{H}_{24}$ & 1781 & $1767^{10}$ & ms $(860,890)$, ri \\
\hline$\alpha$-curcumene (28) & $\mathrm{C}_{15} \mathrm{H}_{22}$ & 1783 & $1784^{11}$ & ms $(845,891)$, ri \\
\hline calamenene (isomer) (29) & $\mathrm{C}_{15} \mathrm{H}_{22}$ & 1846 & $1837^{12}$ & ms $(821,834)$, ri \\
\hline$\alpha$-calacorene (30) & $\mathrm{C}_{15} \mathrm{H}_{20}$ & 1930 & $1920^{13}$ & $\mathrm{~ms}(748,872)$, ri \\
\hline$(Z)$-nerolidol (31) & $\mathrm{C}_{15} \mathrm{H}_{26} \mathrm{O}$ & 2001 & $1993^{6}$ & ms $(877,885)$, ri, std \\
\hline (E)-nerolidol (32) & $\mathrm{C}_{15} \mathrm{H}_{26} \mathrm{O}$ & 2041 & $2041^{14}$ & ms $(837,869)$, ri, std \\
\hline$\alpha$-corocalene (33) & $\mathrm{C}_{15} \mathrm{H}_{20}$ & 2072 & n.a. ${ }^{[\mathrm{e}]}$ & ms $(650,754)$ \\
\hline$\alpha$-bisabolol (34) & $\mathrm{C}_{15} \mathrm{H}_{26} \mathrm{O}$ & 2222 & $2217^{15}$ & ms $(846,917)$, ri, std \\
\hline cadalene (35) & $\mathrm{C}_{15} \mathrm{H}_{18}$ & 2233 & $2231^{16}$ & ms $(743,832)$, ri \\
\hline
\end{tabular}

[a] Unidentified compounds are not listed. [b] Retention index I on a DB-WAX Ultra Inert column. [c] Retention index data from literature. [d] Compound identification is based on matching mass spectrum to a library spectrum (ms, match factor and reverse match factor given in brackets), identical or closely matching retention index (ri) and comparison to a commercially available standard compound (std). [e] Retention index data on a WAX column were not available. 
Table S3. Sesquiterpenes identified in headspace of a fermented aqueous approach consisting of a commercial yeast strain (Saccharomyces cerevisiae), yeast nutrients, $\mathrm{D}(+)$-glucose and $\mathrm{D}(-)$-fructose.

\begin{tabular}{|c|c|c|c|c|}
\hline Sesquiterpene ${ }^{[a]}$ & $\begin{array}{l}\text { Molecular } \\
\text { formula }\end{array}$ & $I^{[\mathrm{b}]}$ & $I$ (lit. $)^{[\mathrm{c}]}$ & Identification $^{[\mathrm{d}]}$ \\
\hline$\alpha$-cedrene (18) & $\mathrm{C}_{15} \mathrm{H}_{24}$ & 1589 & $1600^{1}$ & ms $(851,869)$, ri, std \\
\hline$(E)-\beta$-farnesene (20) & $\mathrm{C}_{15} \mathrm{H}_{24}$ & 1667 & $1668^{3}$ & ms $(900,910)$, ri, std \\
\hline$\alpha$-zingiberene (21) & $\mathrm{C}_{15} \mathrm{H}_{24}$ & 1725 & $1721^{4}$ & ms $(816,891)$, ri \\
\hline$\beta$-bisabolene (22) & $\mathrm{C}_{15} \mathrm{H}_{24}$ & 1734 & $1729^{5}$ & ms $(885,892)$, ri \\
\hline$\beta$-curcumene (24) & $\mathrm{C}_{15} \mathrm{H}_{24}$ & 1746 & $1740^{7}$ & ms $(751,771)$, ri \\
\hline$\alpha$-farnesene $(\mathbf{2 3})$ & $\mathrm{C}_{15} \mathrm{H}_{24}$ & 1750 & $1749^{6}$ & ms $(929,949)$, ri, std \\
\hline$\delta$-cadinene $(\mathbf{2 5})$ & $\mathrm{C}_{15} \mathrm{H}_{24}$ & 1770 & $1770^{8}$ & ms $(757,773)$, ri \\
\hline$\beta$-sesquiphellandrene (26) & $\mathrm{C}_{15} \mathrm{H}_{24}$ & 1777 & $1783^{9}$ & ms $(855,899)$, ri \\
\hline$(E)$ - $\alpha$-bisabolene $(\mathbf{2 7})$ & $\mathrm{C}_{15} \mathrm{H}_{24}$ & 1779 & $1767^{10}$ & ms $(841,871)$, ri \\
\hline$\alpha$-curcumene (28) & $\mathrm{C}_{15} \mathrm{H}_{22}$ & 1780 & $1784^{11}$ & ms $(871,900)$, ri \\
\hline calamenene (isomer) (29) & $\mathrm{C}_{15} \mathrm{H}_{22}$ & 1844 & $1837^{12}$ & ms $(792,807)$, ri \\
\hline$(E)$-nerolidol (32) & $\mathrm{C}_{15} \mathrm{H}_{26} \mathrm{O}$ & 2038 & $2041^{14}$ & ms $(876,886)$, ri, std \\
\hline$\alpha$-bisabolol (34) & $\mathrm{C}_{15} \mathrm{H}_{26} \mathrm{O}$ & 2217 & $2217^{15}$ & ms $(725,784)$, ri, std \\
\hline farnesol (36) & $\mathrm{C}_{15} \mathrm{H}_{26} \mathrm{O}$ & 2354 & $2354^{17}$ & ms $(904,904)$, ri, std \\
\hline
\end{tabular}

[a] Unidentified compounds are not listed. [b] Retention index I on a DB-WAX Ultra Inert column. [c] Retention index data from literature. [d] Compound identification is based on matching mass spectrum to a library spectrum (ms, match factor and reverse match factor given in brackets), identical or closely matching retention index (ri) and comparison to a commercially available standard compound (std). 
Table S4. Pairs of genuine and deuterated sesquiterpene hydrocarbons after ex vivo tissue deuterium-labeling using $d_{3}$-MVL as the precursor, which were detected both before microvinification in the exocarp of Lemberger berries and after microvinification in Lemberger model wine.

\begin{tabular}{|c|c|c|c|c|}
\hline Sesquiterpene $\mathrm{e}^{[\mathrm{a}]}$ & $\begin{array}{l}\text { Molecular } \\
\text { formula }\end{array}$ & $I^{[\mathrm{b}]}$ & $I$ (lit. $^{[\mathrm{c}]}$ & Identification $^{[\mathrm{d}]} /$ Verification $^{[\mathrm{e}]}$ \\
\hline$d_{0}-\alpha$-ylangene (8a) & $\mathrm{C}_{15} \mathrm{H}_{24}$ & 1502 & $1502^{18}$ & ms $(874,883)$, ri, $d_{3}-\mathrm{MVL}$ \\
\hline 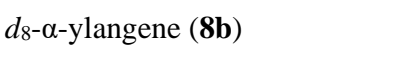 & $\mathrm{C}_{15} \mathrm{H}_{16} \mathrm{D}_{8}$ & 1494 & n.a. ${ }^{[\mathrm{f}]}$ & $\mathrm{ms}$ \\
\hline 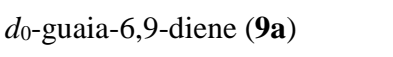 & $\mathrm{C}_{15} \mathrm{H}_{24}$ & 1619 & n.a. ${ }^{[\mathrm{f}]}$ & $\mathrm{ms}(846,853), d_{3}-\mathrm{MVL}$ \\
\hline 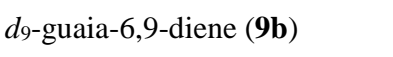 & $\mathrm{C}_{15} \mathrm{H}_{15} \mathrm{D}_{9}$ & 1610 & n.a. ${ }^{[\mathrm{f}]}$ & $\mathrm{ms}$ \\
\hline$d_{0}-\delta$-selinene $(\mathbf{1 0 a})$ & $\mathrm{C}_{15} \mathrm{H}_{24}$ & 1705 & n.a. ${ }^{[\mathrm{f}]}$ & $\mathrm{ms}(838,881), d_{3}-\mathrm{MVL}$ \\
\hline$d_{9-\delta} \delta$-selinene $(\mathbf{1 0 b})$ & $\mathrm{C}_{15} \mathrm{H}_{15} \mathrm{D}_{9}$ & 1697 & n.a. ${ }^{[\mathrm{f}]}$ & $\mathrm{ms}$ \\
\hline$d_{0}-\delta$-cadinene (11a) & $\mathrm{C}_{15} \mathrm{H}_{24}$ & 1769 & $1770^{8}$ & ms $(831,894)$, ri, $d_{3}-\mathrm{MVL}$ \\
\hline$d_{8}$ - $\delta$-cadinene $(\mathbf{1 1 b})$ & $\mathrm{C}_{15} \mathrm{H}_{16} \mathrm{D}_{8}$ & 1762 & n.a. ${ }^{[\mathrm{f}]}$ & $\mathrm{ms}$ \\
\hline$d_{0}$-selina-3,7(11)-diene (12a) & $\mathrm{C}_{15} \mathrm{H}_{24}$ & 1797 & $1783^{19}$ & ms $(848,871)$, ri, $d_{3}-\mathrm{MVL}$ \\
\hline$d_{9}$-selina-3,7(11)-diene (12b) & $\mathrm{C}_{15} \mathrm{H}_{15} \mathrm{D}_{9}$ & 1787 & n.a. ${ }^{[\mathrm{f}]}$ & $\mathrm{ms}$ \\
\hline$d_{0}$-calamenene (isomer) (13a) & $\mathrm{C}_{15} \mathrm{H}_{22}$ & 1847 & $1837^{12}$ & ms $(806,820)$, ri, $d_{3}-\mathrm{MVL}$ \\
\hline 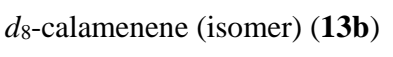 & $\mathrm{C}_{15} \mathrm{H}_{14} \mathrm{D}_{8}$ & 1838 & n.a. ${ }^{[\mathrm{f}]}$ & $\mathrm{ms}$ \\
\hline$d_{0}-\alpha$-calacorene $(\mathbf{1 4 a})$ & $\mathrm{C}_{15} \mathrm{H}_{20}$ & 1930 & $1920^{13}$ & ms $(799,890)$, ri, $d_{3}-\mathrm{MVL}$ \\
\hline$d_{8-\alpha \text {-calacorene }(\mathbf{1 4 b})}$ & $\mathrm{C}_{15} \mathrm{H}_{12} \mathrm{D}_{8}$ & 1922 & n.a. ${ }^{[\mathrm{f}]}$ & $\mathrm{ms}$ \\
\hline$d_{0}-\alpha$-corocalene $(\mathbf{1 5 a})$ & $\mathrm{C}_{15} \mathrm{H}_{20}$ & 2072 & n.a. ${ }^{[\mathrm{f}]}$ & $\mathrm{ms}(710,815), d_{3}-\mathrm{MVL}$ \\
\hline$d_{8}-\alpha$-corocalene $(\mathbf{1 5 b})$ & $\mathrm{C}_{15} \mathrm{H}_{12} \mathrm{D}_{8}$ & 2065 & n.a. ${ }^{[\mathrm{f}]}$ & $\mathrm{ms}$ \\
\hline$d_{0}$-cadalene (16a) & $\mathrm{C}_{15} \mathrm{H}_{18}$ & 2233 & $2231^{16}$ & ms $(867,877)$, ri, $d_{3}-\mathrm{MVL}$ \\
\hline$d_{8}$-cadalene $(\mathbf{1 6} \mathbf{b})$ & $\mathrm{C}_{15} \mathrm{H}_{10} \mathrm{D}_{8}$ & 2224 & n.a. ${ }^{[\mathrm{f}]}$ & $\mathrm{ms}$ \\
\hline$d_{0 \text {-guaiazulene }(\mathbf{1 7 a})}$ & $\mathrm{C}_{15} \mathrm{H}_{18}$ & 2415 & n.a. ${ }^{[\mathrm{f}]}$ & ms $(770,793)$, std, $d_{3}-\mathrm{MVL}$ \\
\hline$d_{9 \text {-guaiazulene }(\mathbf{1 7 b})}$ & $\mathrm{C}_{15} \mathrm{H}_{9} \mathrm{D}_{9}$ & 2405 & n.a. ${ }^{[\mathrm{f}]}$ & $\mathrm{ms}$ \\
\hline
\end{tabular}

[a] Unidentified compounds are not listed. [b] Retention index I on a DB-WAX Ultra Inert column. [c] Retention index data from literature. [d] Compound identification is based on matching mass spectrum to a library spectrum (ms, match factor and reverse match factor given in brackets), identical or closely matching retention index (ri) and comparison to a commercially available standard compound (std). [e] Verification of the found sesquiterpenes was carried out by ex vivo tissue deuterium-labeling with $\left[6,6,6-{ }^{2} \mathrm{H}_{3}\right]-( \pm)$-mevalonolactone $\left(d_{3}-\mathrm{MVL}\right)$ as stable isotope-labeled precursor. [f] Retention index data on a WAX column were not available. 


\section{FIGURES}

A)

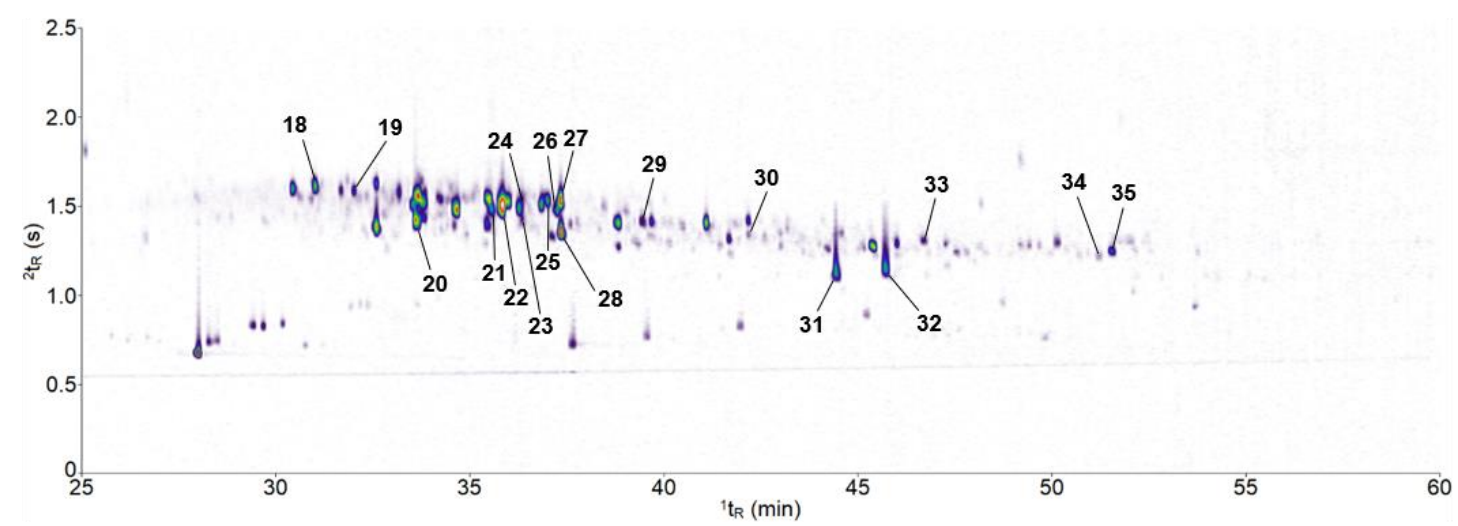

B)

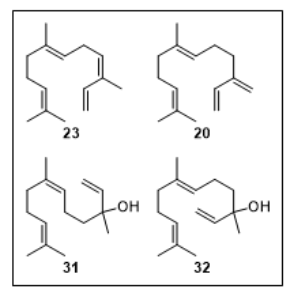

Farnesanes

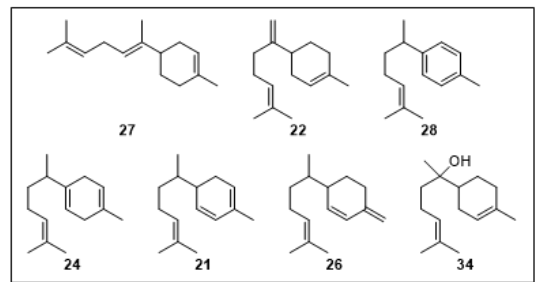

Bisabolanes
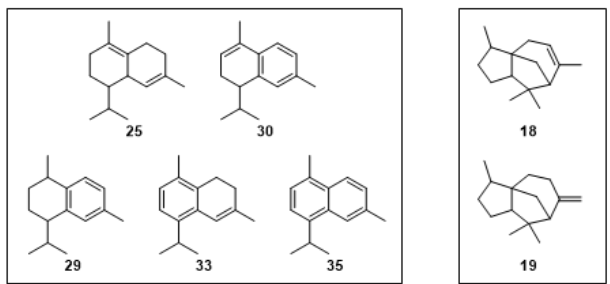

Cadinanes

Cedranes

Figure S1. HS-SPME-GC $\times$ GC-TOF-MS analysis of an acidified, aqueous nerolidol solution (sample volume $1 \mathrm{~mL}$; concentration $1 \mathrm{mg} / \mathrm{L}$; acidified to $\mathrm{pH} 3.3$ using L(-)-malic acid; preincubation temperature $30{ }^{\circ} \mathrm{C}$ ) to investigate the acid-catalyzed formation of sesquiterpenes. A) Section of a $2 \mathrm{D}$ chromatogram (EIC 198, 200, 202, 204). The ${ }^{1} t_{R}$ (X-axis) corresponds to the retention time on the first dimension (1D) column and ${ }^{2} t_{R}$ (Y-axis) to the retention time on the secondary (2D) column. The color gradient reflects the intensity of the TOF-MS signal on a white background from low (violet) to high (red). Numbers at peaks refer to compound numbers as defined in Table S2. B) Structural formulas of the identified sesquiterpenes, grouped according to the type of their sesquiterpene skeleton. 
A)

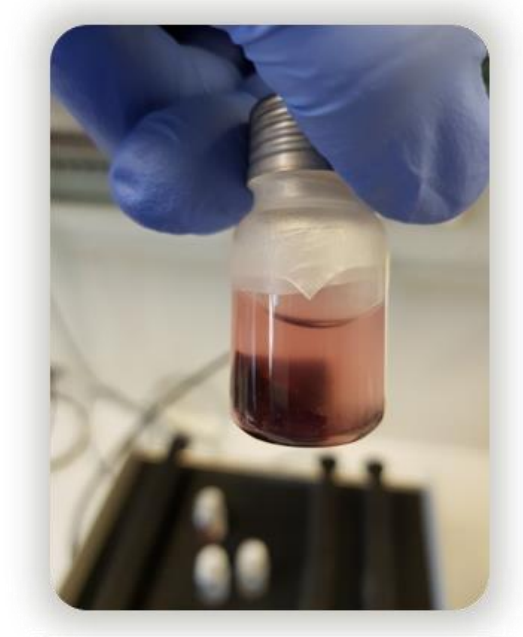

$d_{3}$-MVL labeled exocarp

D-glucose

D-fructose

water

yeast nutrients

commercial yeast strain
B)
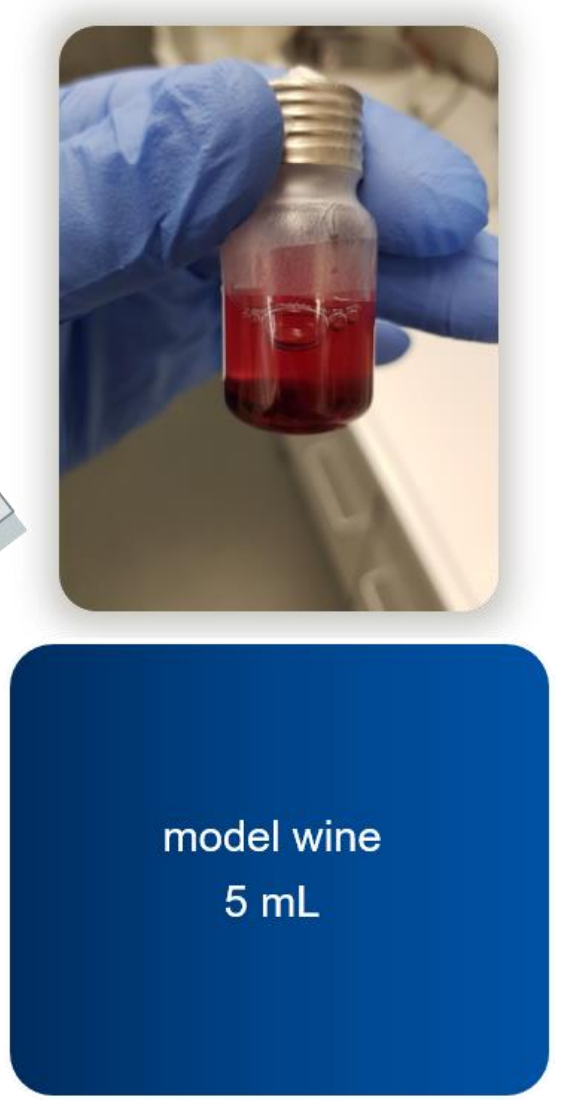

Figure S2. Microvinification. A) Aqueous approach consisting of labeled exocarp, D(+)-glucose, D(-)-fructose, yeast nutrients and yeast in a $10 \mathrm{~mL}$ headspace vial at the beginning of fermentation. B) Model wine after 7 days microvinification at room temperature. In addition to the intensive red coloration, gas formation is clearly visible. 
A)

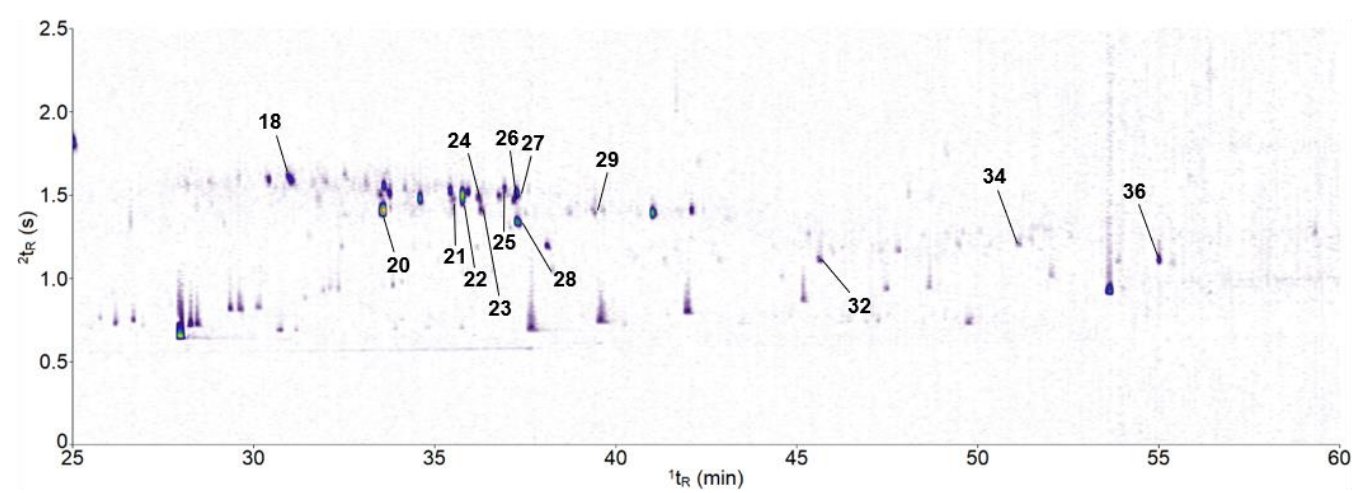

B)

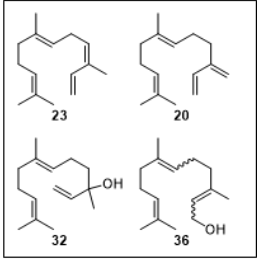

Farnesanes

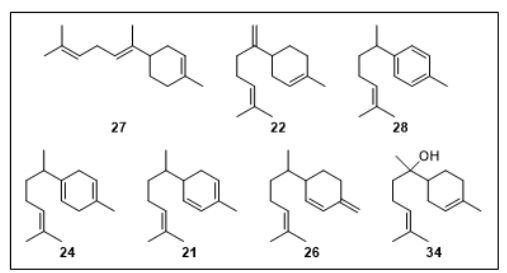

Bisabolanes

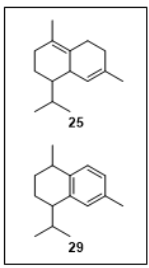

Cadinanes

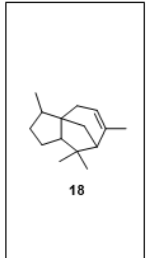

Cedranes

Figure S3. Headspace analysis of a fermented aqueous approach consisting of a commercial yeast strain (Saccharomyces cerevisiae), yeast nutrients, D(+)-glucose and D(-)-fructose. A) Contour plot of a HS-SPME-GC $\times$ GC-TOF-MS chromatogram (EIC 198, 202, 204). ${ }^{1} t_{R}$ corresponds to the retention time on the highly polar first GC column and ${ }^{2} t_{R}$ on the mid-polar second column. Peak intensities are reproduced by changing color from violet (low TOF-MS signal) to red (high TOF-MS signal) on a white background. B) Structural formulas of the identified sesquiterpenes, grouped according to the type of their sesquiterpene skeleton. The numbering of peaks and structures is identical to the numbering in Table S3. 

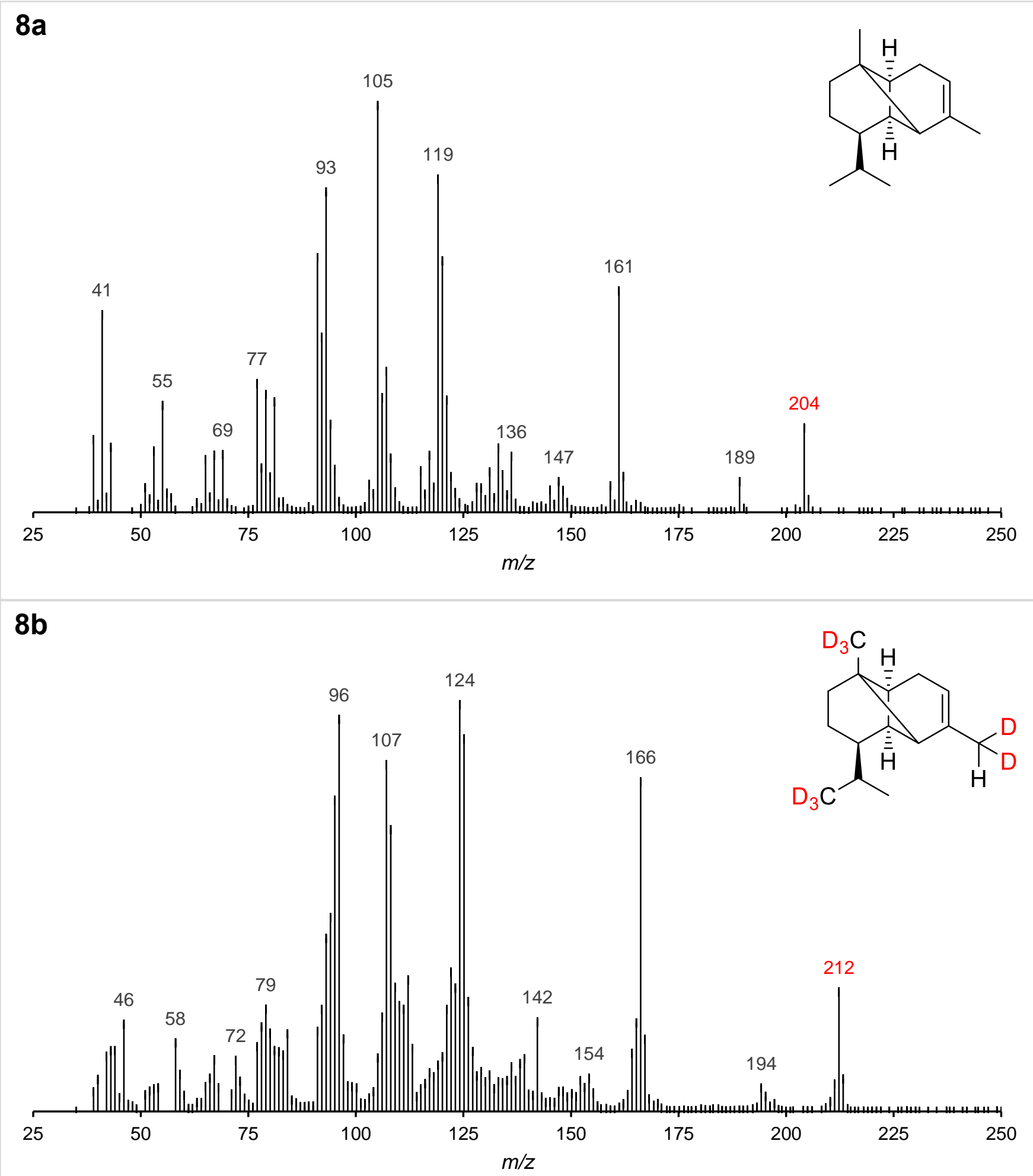

Figure S4. MS spectra and expected labeling patterns of $8 \mathrm{a}: d_{0}-\alpha$-ylangene and $8 \mathrm{~b}$ : $d_{8}$ - $\alpha$-ylangene in Lemberger model wine after administration of $\left[6,6,6-{ }^{2} \mathrm{H}_{3}\right]-( \pm)$-mevalonolactone $\left(d_{3}-\mathrm{MVL}\right)$ to isolated exocarp of grape berries and microvinification. 

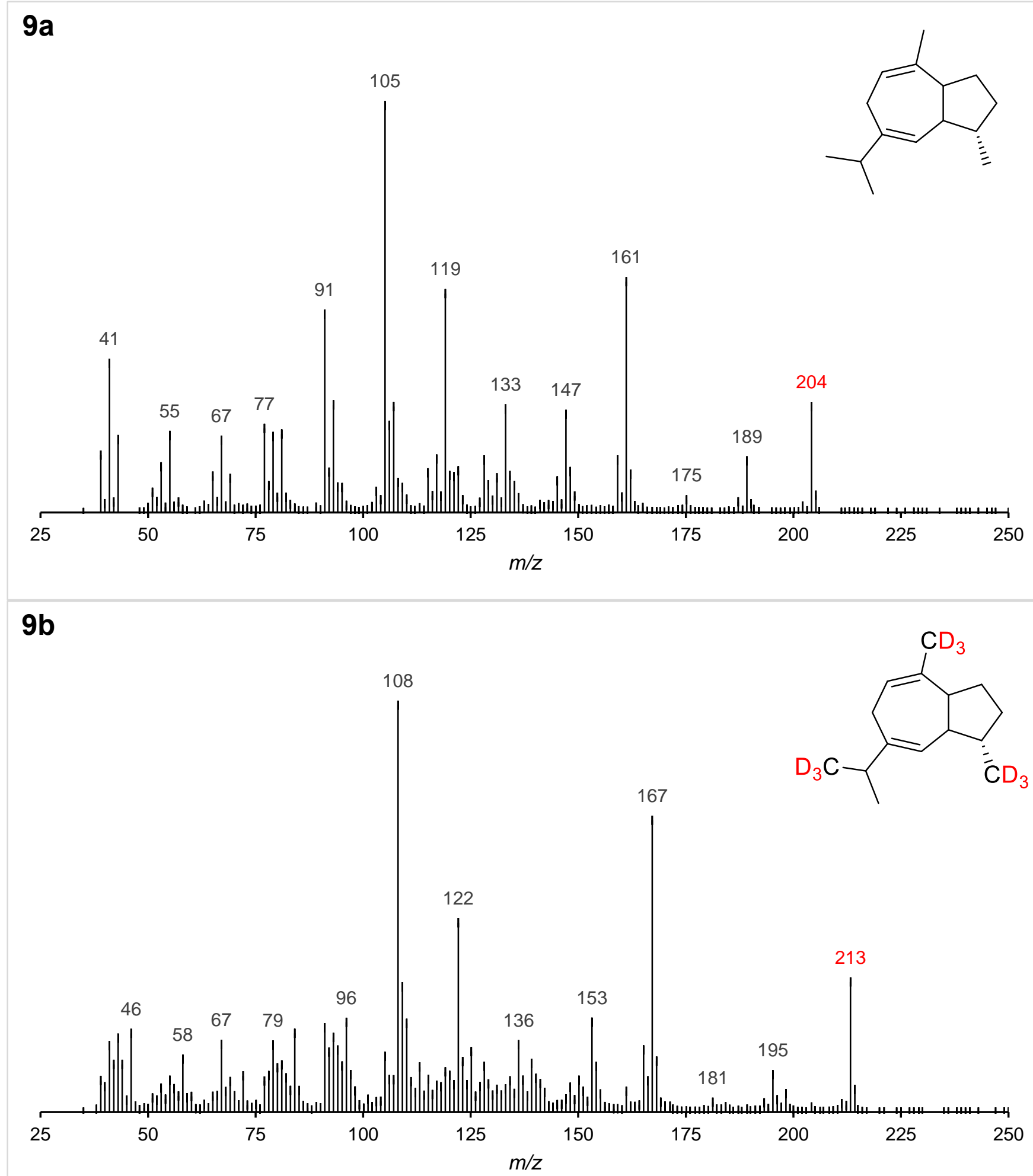

Figure S5. MS spectra and expected labeling patterns of 9a: $d_{0}$-guaia-6,9-diene and 9b: $d_{9}$-guaia-6,9-diene in Lemberger model wine after administration of $\left[6,6,6-{ }^{2} \mathrm{H}_{3}\right]-( \pm)$-mevalonolactone $\left(d_{3}\right.$-MVL) to isolated exocarp of grape berries and microvinification. 


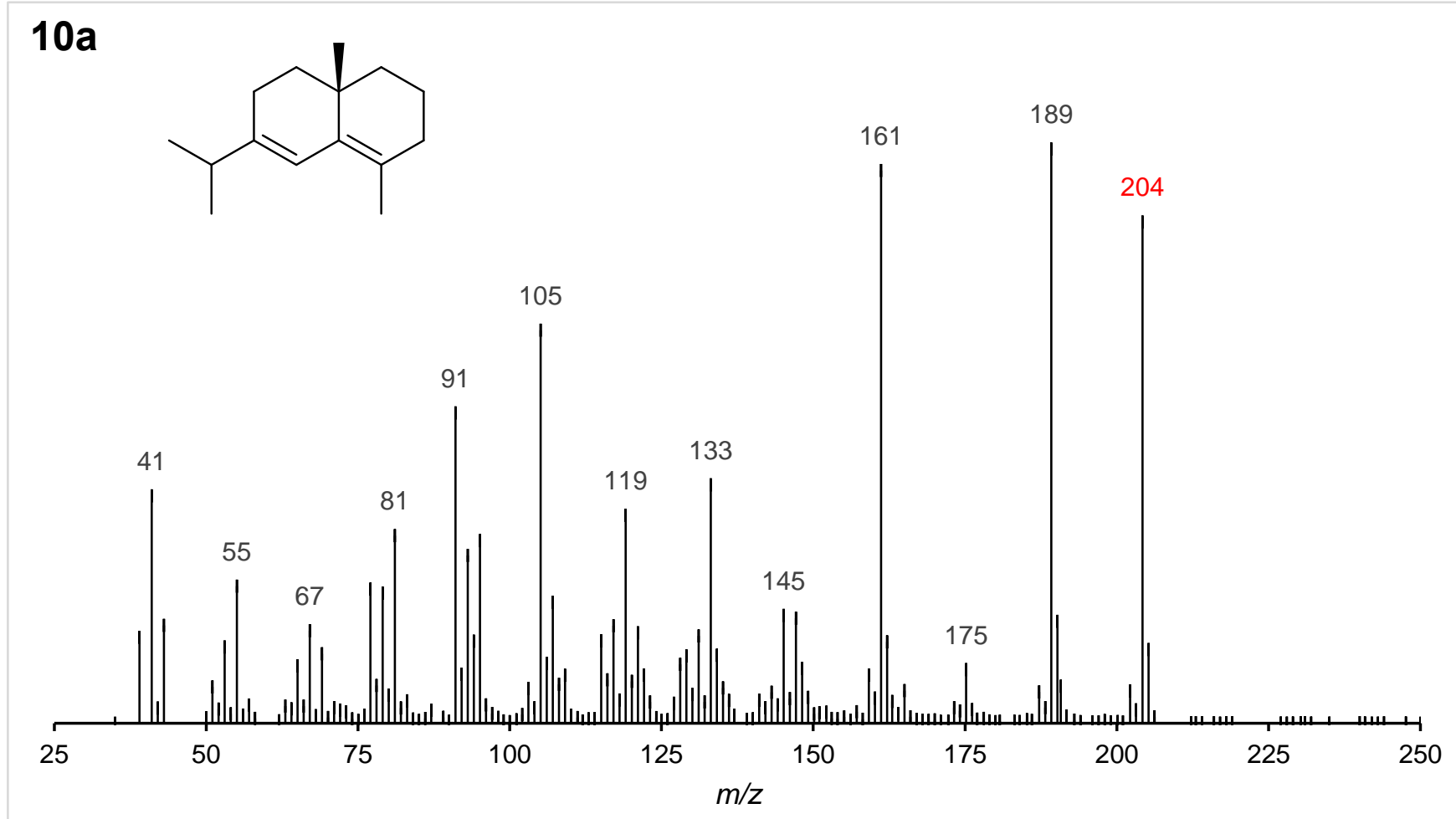

\section{$10 b$}<smiles>[2H]C([2H])([2H])C(C)C1=CC2=C(C(C)(C)C)CCC[C@]2(C)CC1</smiles>

25

50

75

125

175

$m / z$

Figure S6. MS spectra and expected labeling patterns of 10a: $d_{0}-\delta$-selinene and 10b: $d_{9}-\delta$-selinene in Lemberger model wine after administration of $\left[6,6,6-{ }^{2} \mathrm{H}_{3}\right]-( \pm)$-mevalonolactone $\left(d_{3}-\mathrm{MVL}\right)$ to isolated exocarp of grape berries and microvinification. 


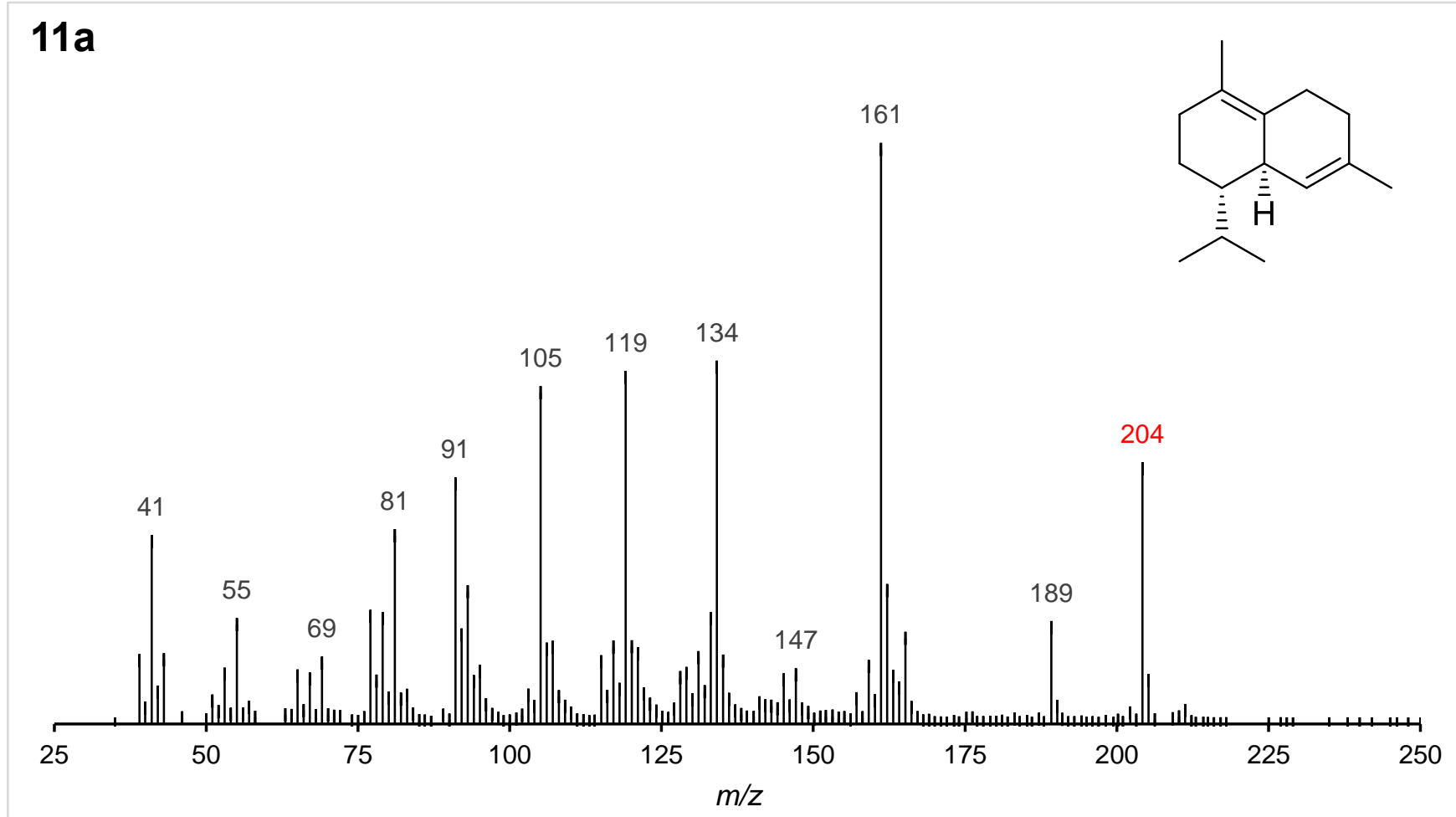

\section{$11 b$}

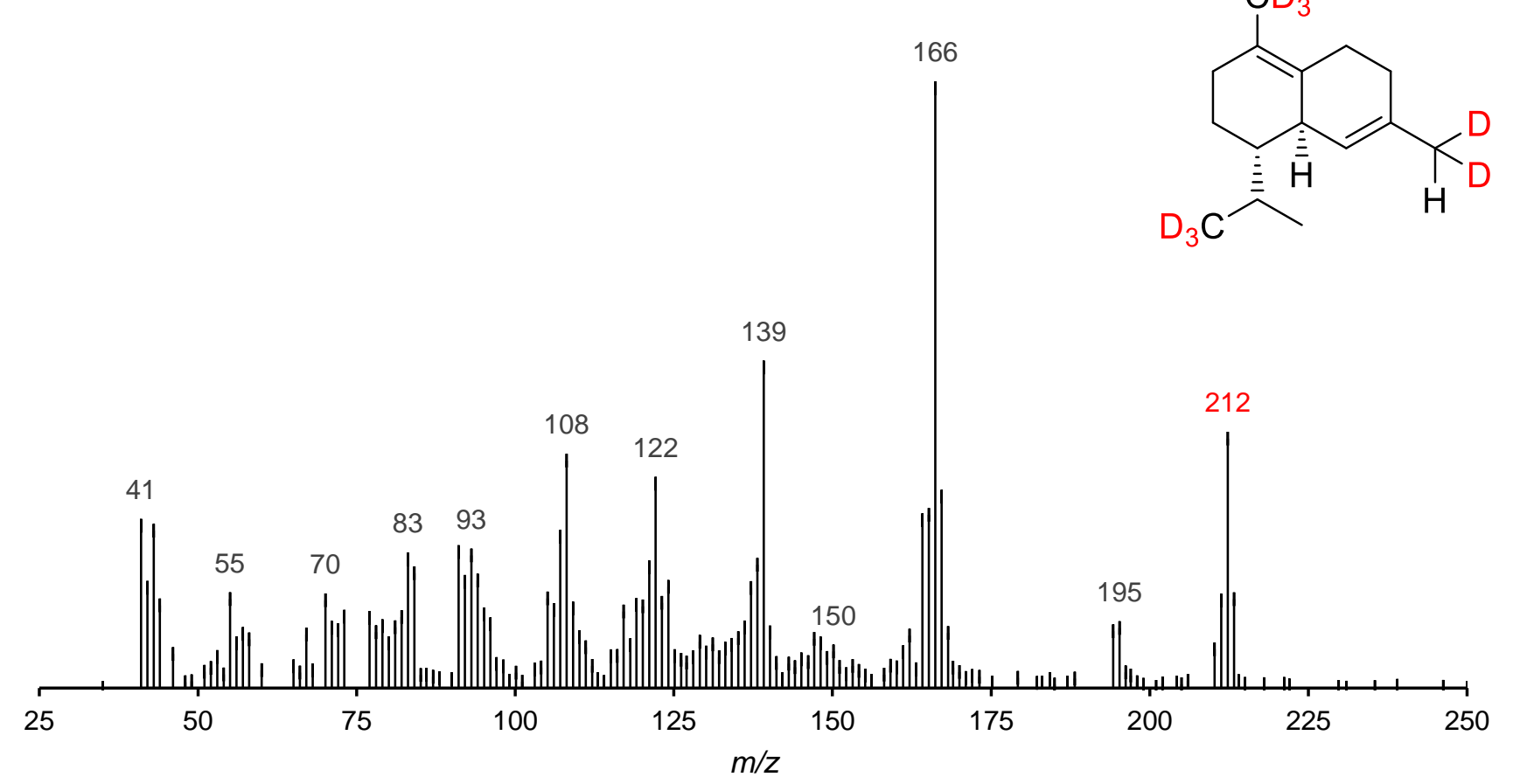

Figure S7. MS spectra and expected labeling patterns of $11 \mathrm{a}: d_{0}-\delta$-cadinene and $11 \mathrm{~b}: d_{8}-\delta$-cadinene in Lemberger model wine after administration of $\left[6,6,6-{ }^{2} \mathrm{H}_{3}\right]-( \pm)$-mevalonolactone $\left(d_{3}-\mathrm{MVL}\right)$ to isolated exocarp of grape berries and microvinification. 

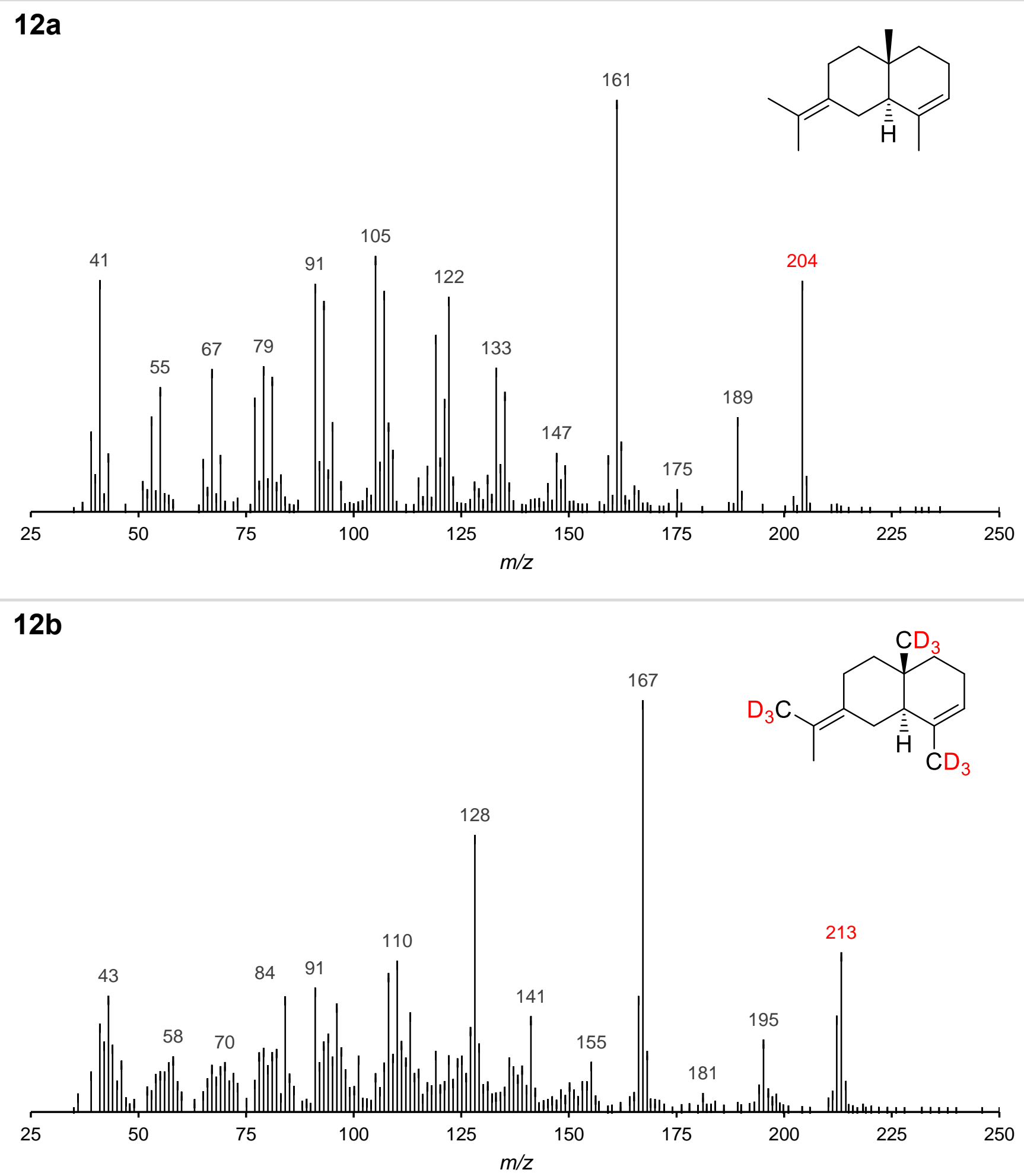

Figure S8. MS spectra and expected labeling patterns of 12a: $d_{0}$-selina-3,7(11)-diene and 12b: $d_{9}$-selina-3,7(11)-diene in Lemberger model wine after administration of $\left[6,6,6-{ }^{2} \mathrm{H}_{3}\right]-( \pm)$-mevalonolactone $\left(d_{3}\right.$-MVL) to isolated exocarp of grape berries and microvinification. 


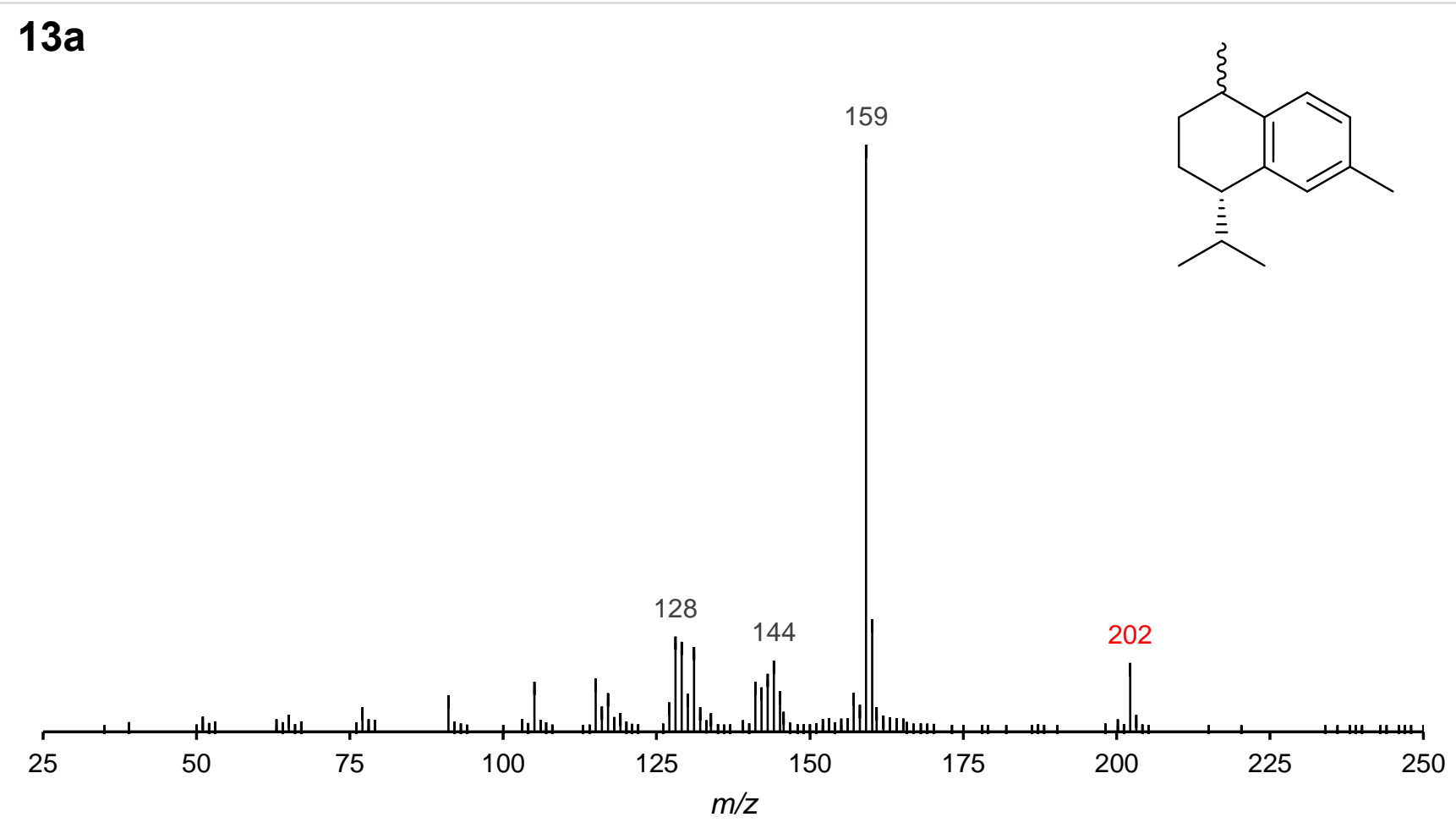

\section{$13 b$}

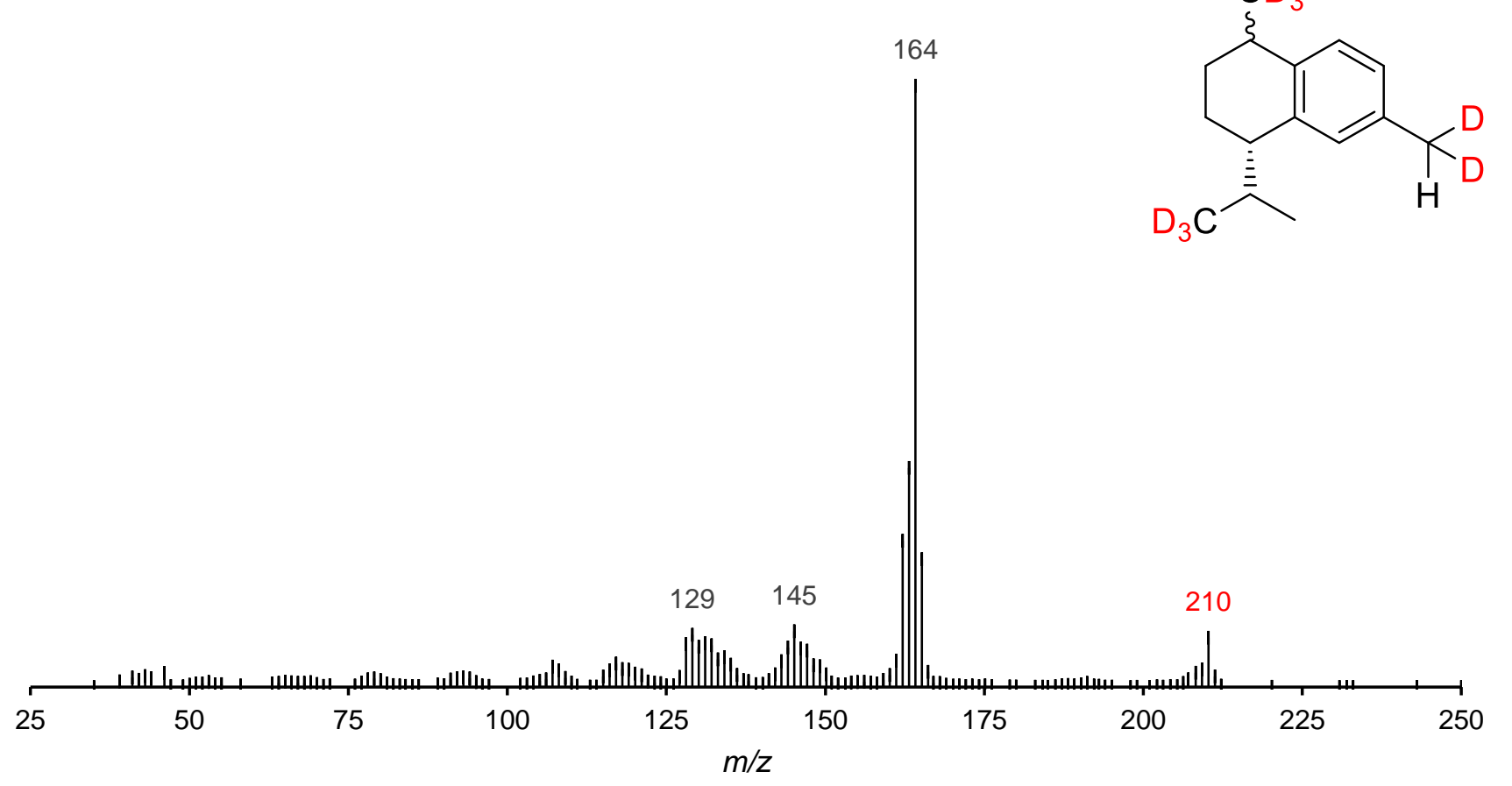

Figure S9. MS spectra and expected labeling patterns of 13a: $d_{0}$-calamenene (isomer) and 13b: $d_{8}$-calamenene (isomer) in Lemberger model wine after administration of $\left[6,6,6-{ }^{2} \mathrm{H}_{3}\right]-( \pm)$-mevalonolactone $\left(d_{3}-\mathrm{MVL}\right)$ to isolated exocarp of grape berries and microvinification. 


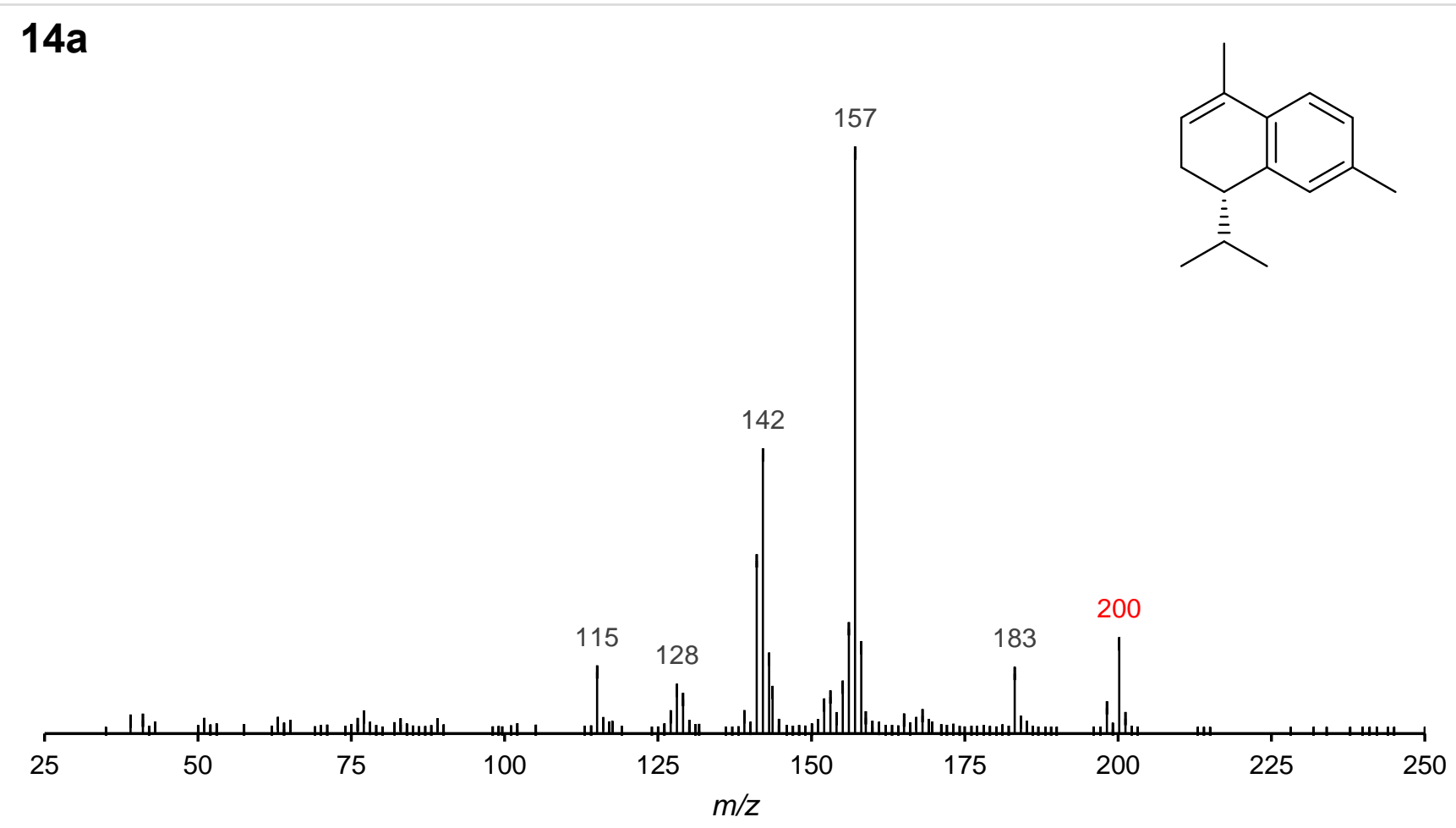

\section{$14 b$}

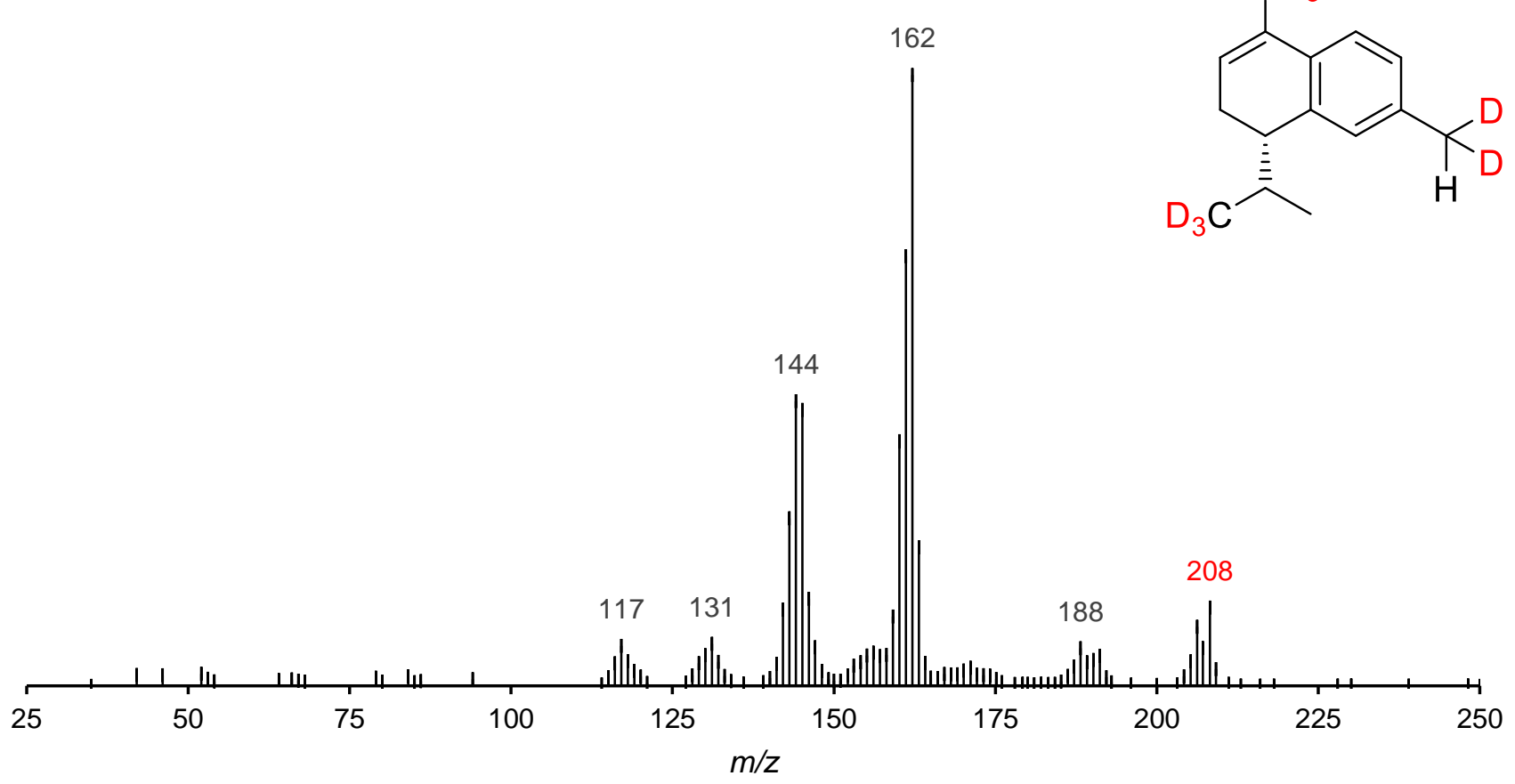

Figure S10. MS spectra and expected labeling patterns of $14 \mathrm{a}: d_{0}-\alpha$-calacorene and $14 \mathrm{~b}$ : $d_{8}$ - $\alpha$-calacorene in Lemberger model wine after administration of $\left[6,6,6-{ }^{2} \mathrm{H}_{3}\right]-( \pm)$-mevalonolactone $\left(d_{3}\right.$-MVL) to isolated exocarp of grape berries and microvinification. 


\section{$15 a$}<smiles>CC1=Cc2c(C(C)C)ccc(C)c2CC1</smiles>

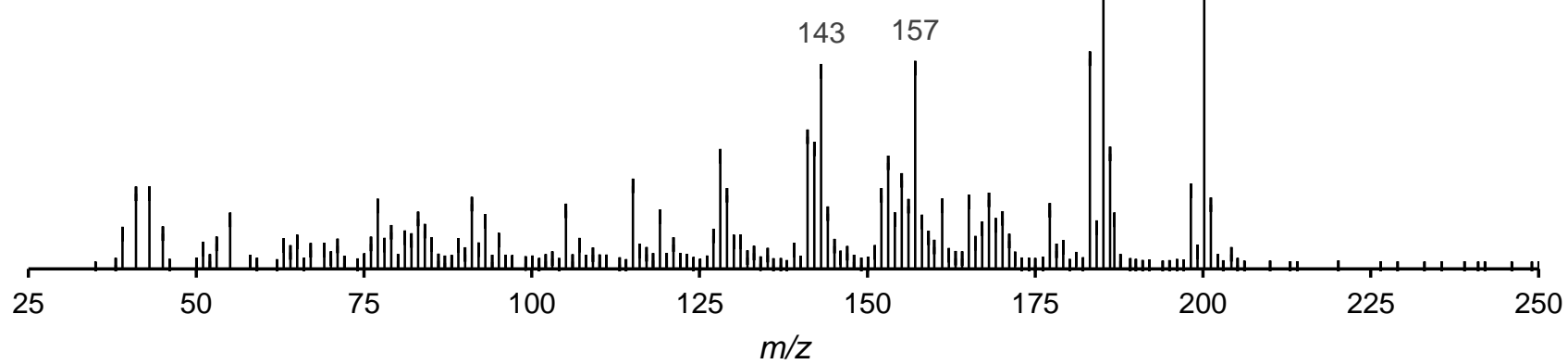

\section{$15 b$}

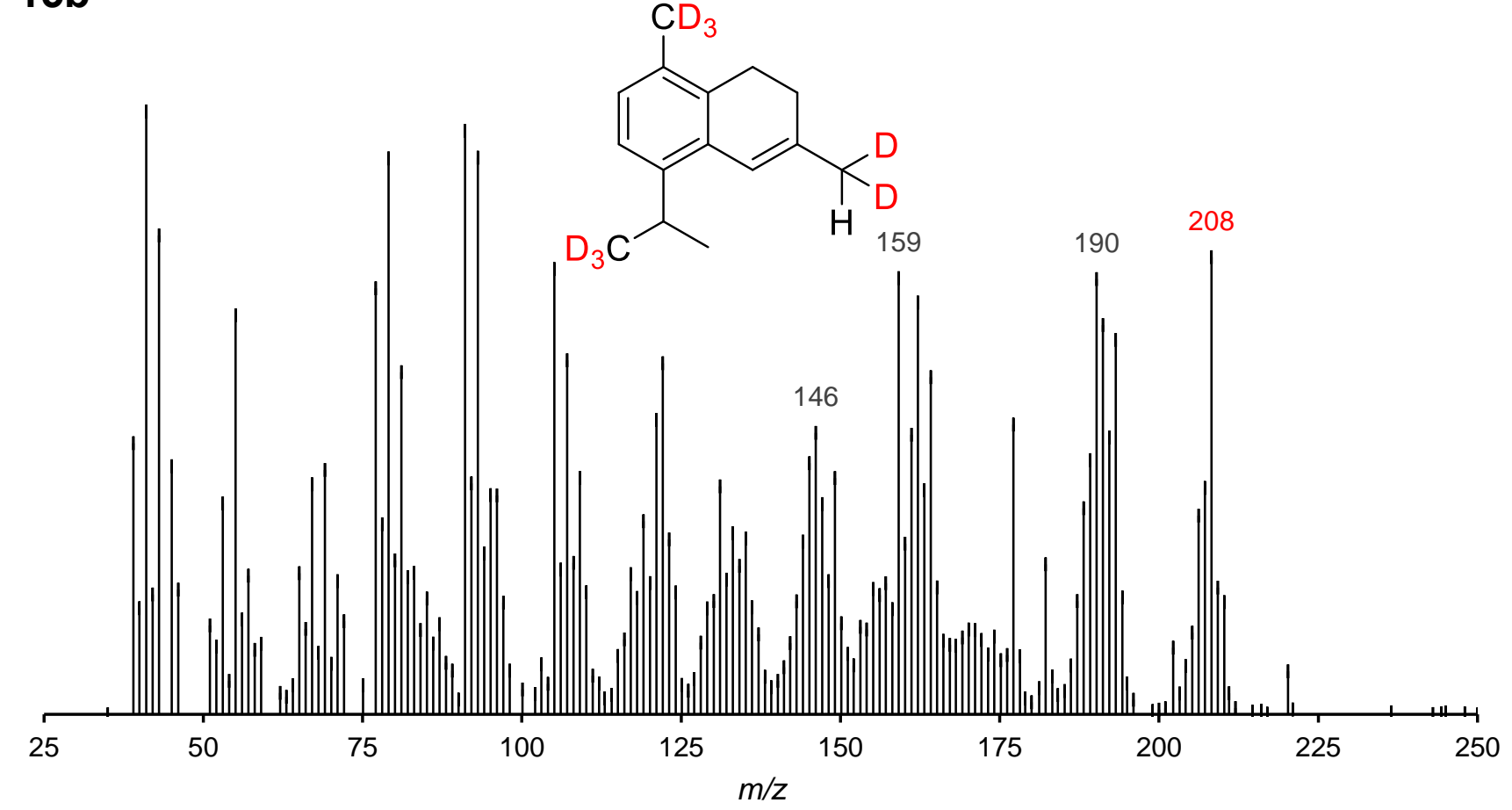

Figure S11. MS spectra and expected labeling patterns of $15 \mathrm{a}: d_{0}-\alpha$-corocalene and $15 \mathrm{~b}$ : $d_{8}-\alpha$-corocalene in Lemberger model wine after administration of $\left[6,6,6{ }^{2} \mathrm{H}_{3}\right]-( \pm)$-mevalonolactone $\left(d_{3}-\mathrm{MVL}\right)$ to isolated exocarp of grape berries and microvinification. 


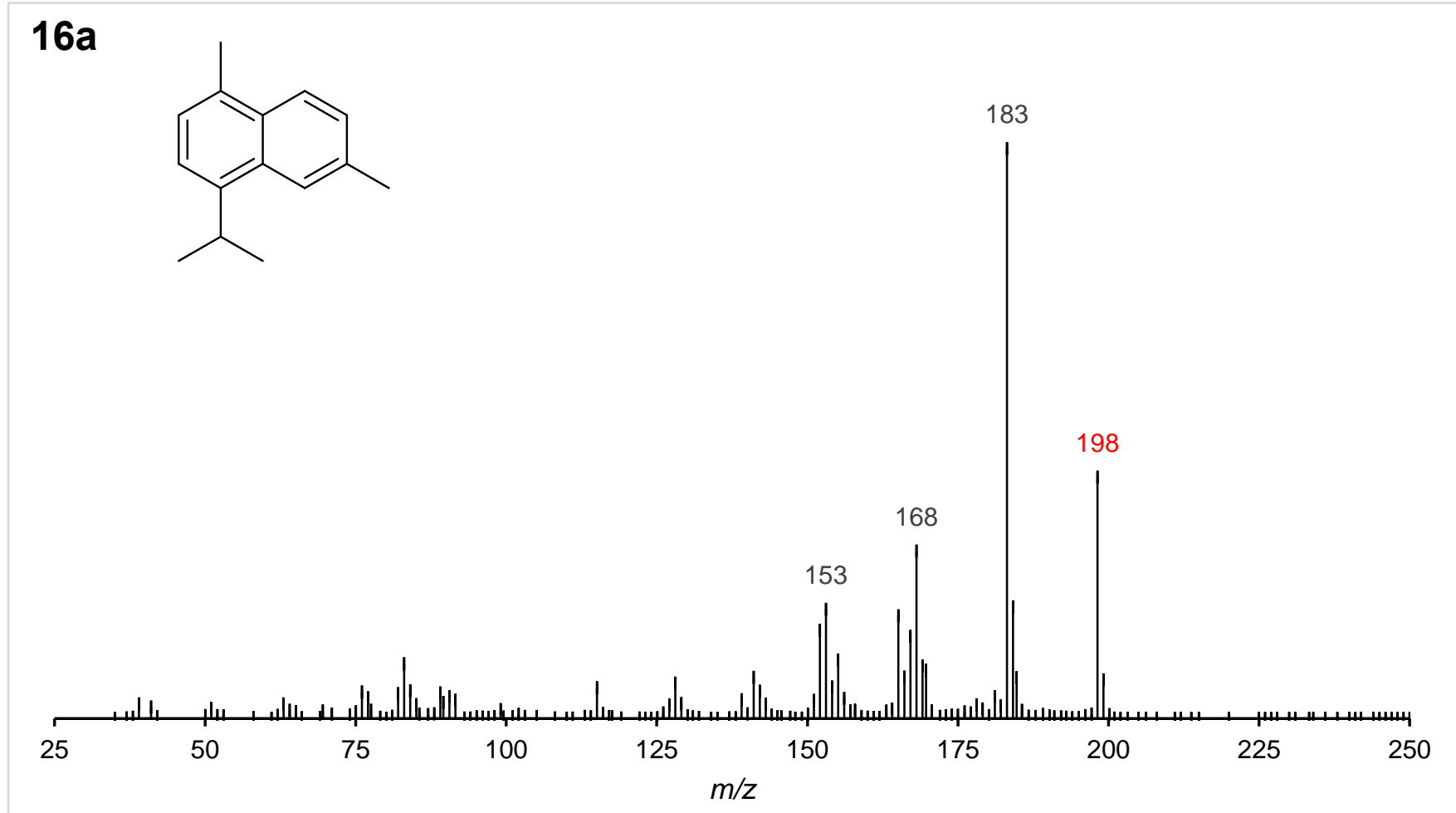

\section{$16 b$}

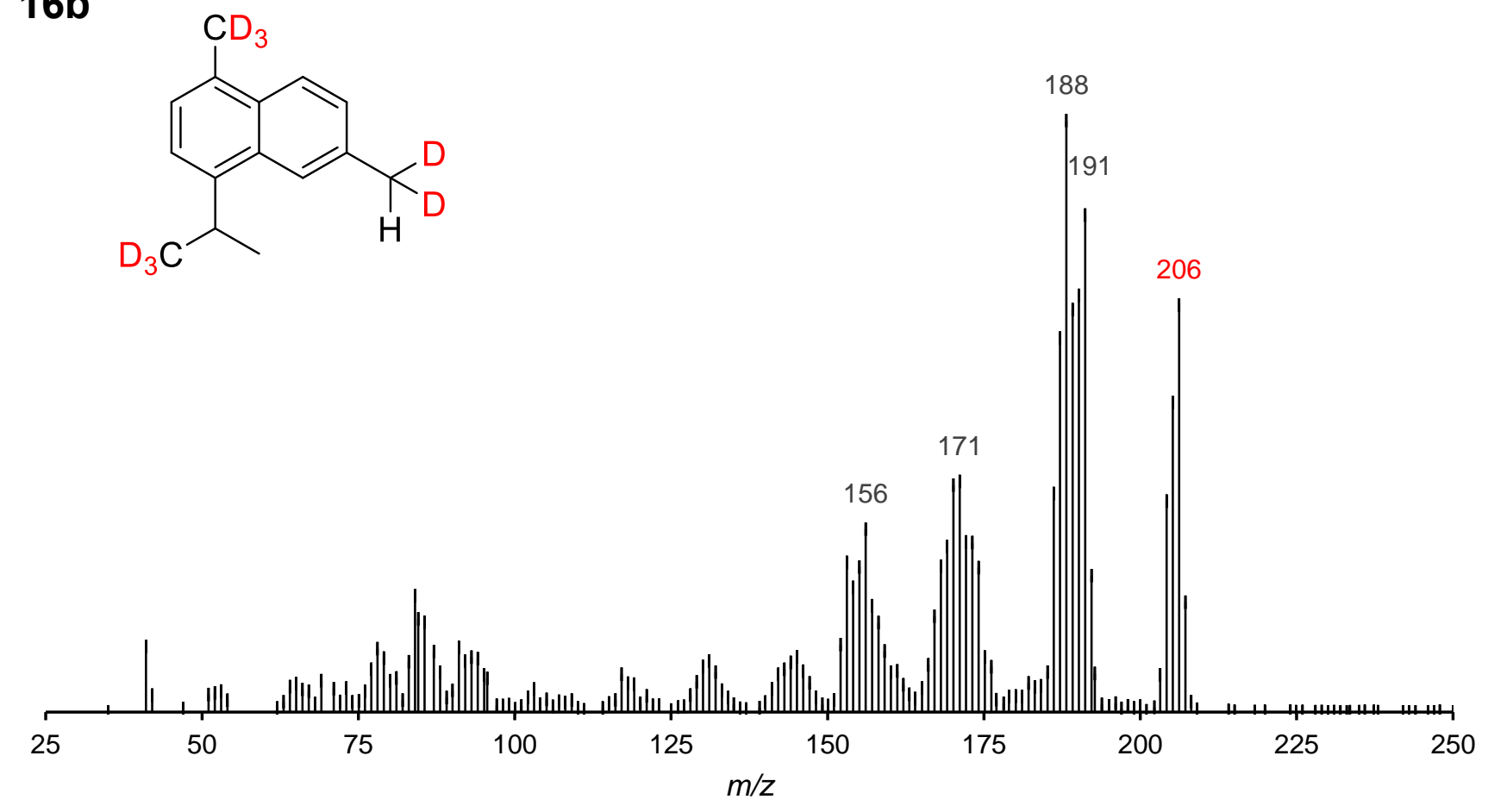

Figure S12. MS spectra and expected labeling patterns of $16 \mathrm{a}: d_{0}$-cadalene and $16 \mathrm{~b}: d_{8}$-cadalene in Lemberger model wine after administration of $\left[6,6,6-{ }^{2} \mathrm{H}_{3}\right]-( \pm)$-mevalonolactone $\left(d_{3}-\mathrm{MVL}\right)$ to isolated exocarp of grape berries and microvinification. 


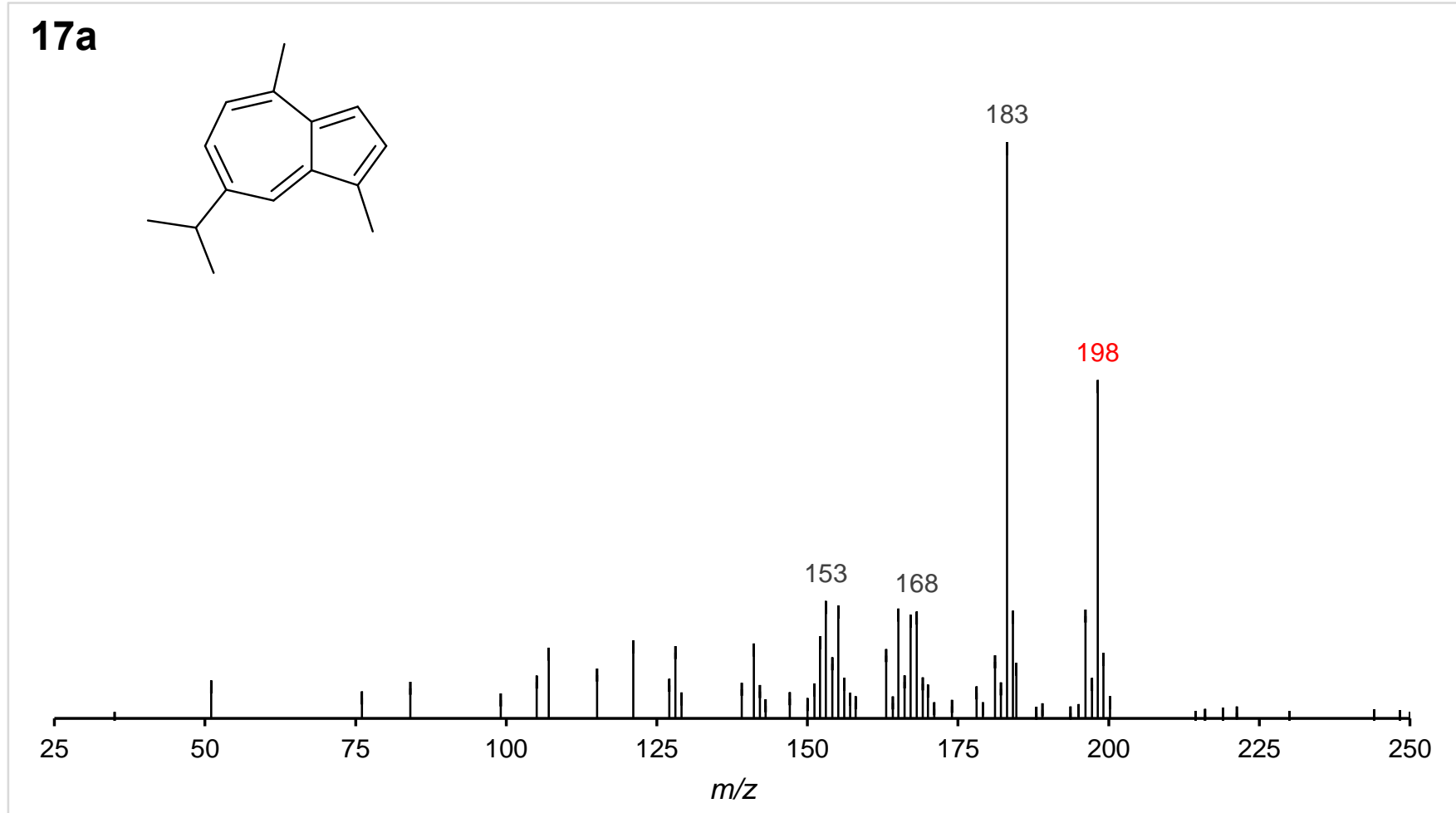

\section{7b}

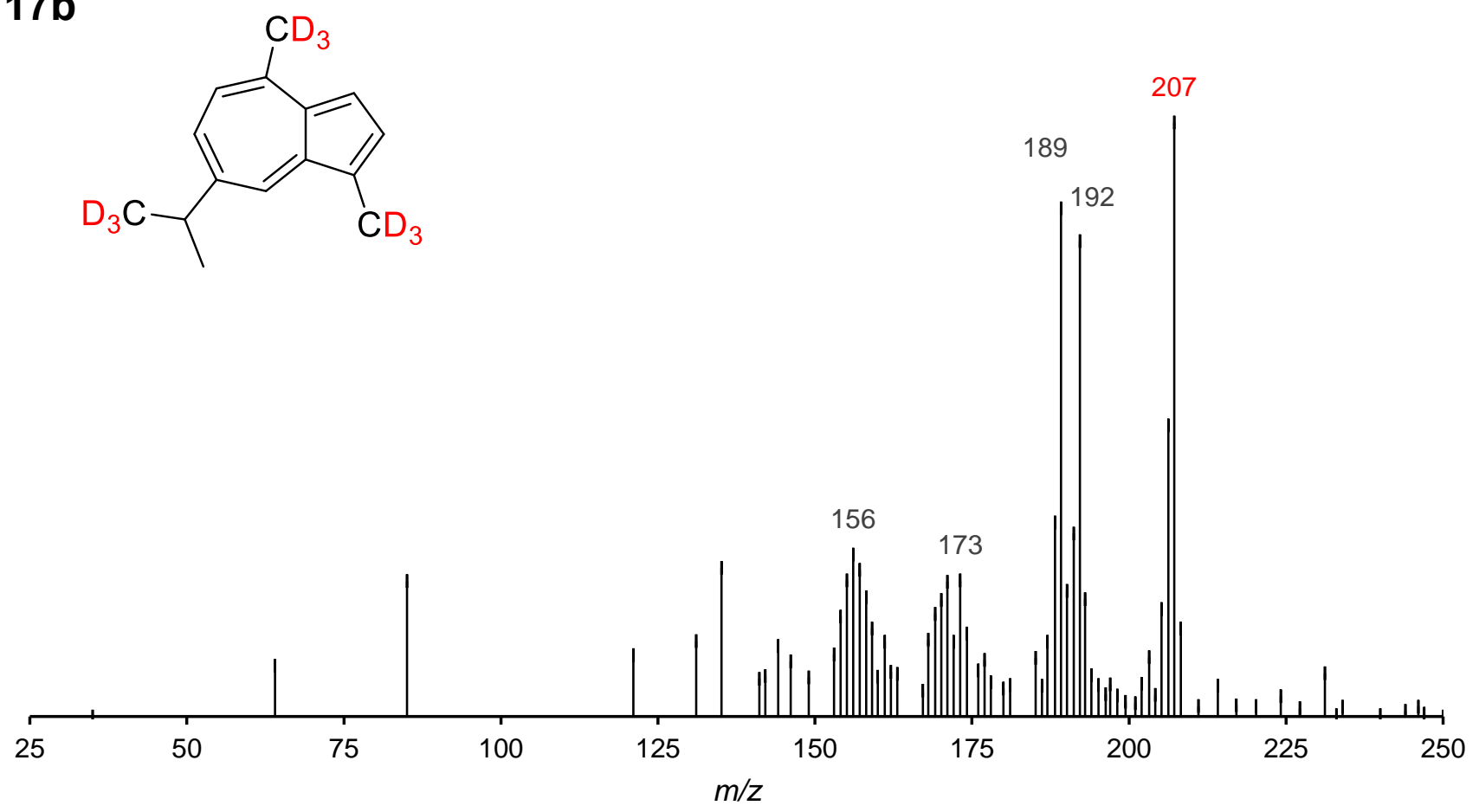

Figure S13. MS spectra and expected labeling patterns of $17 \mathrm{a}: d_{0}$-guaiazulene and $17 \mathrm{~b}$ : $d_{9}$-guaiazulene in Lemberger model wine after administration of $\left[6,6,6-{ }^{2} \mathrm{H}_{3}\right]-( \pm)$-mevalonolactone $\left(d_{3}-\mathrm{MVL}\right)$ to isolated exocarp of grape berries and microvinification. 


\section{REFERENCES}

(1) Chanegriha, N.; Baaliouamer, A.; Rolando, C. Polarity changes during capillary gas chromatographic and gas chromatographic-mass spectrometric analysis using serially coupled columns of different natures and temperature programming Application to the identification of constituents of essential oils. J. Chromatogr. A 1998, 819, 61-65.

(2) Bertoli, A.; Pistelli, L.; Morelli, I.; Fraternale, D.; Giamperi, L.; Ricci, D. Volatile constituents of different parts (roots, stems and leaves) of Smyrnium olusatrum L..$^{\dagger}$ Flavour Fragr. J. 2004, 19, 522-525.

(3) Lazari, D. M.; Skaltsa, H. D.; Constantinidis, T. Volatile constituents of Cerastium candidissimum, a Greek endemic species. Flavour Fragr. J. 2000, 15, 174-176.

(4) Bortolomeazzi, R.; Berno, P.; Pizzale, L.; Conte, L. S. Sesquiterpene, Alkene, and Alkane Hydrocarbons in Virgin Olive Oils of Different Varieties and Geographical Origins. J. Agric. Food Chem. 2001, 49, 3278-3283.

(5) Kundakovic, T.; Fokialakis, N.; Kovacevic, N.; Chinou, I. Essential oil composition of Achillea lingulata and A. umbellata. Flavour Fragr. J. 2007, 22, 184-187.

(6) Romeo, V.; Ziino, M.; Giuffrida, D.; Condurso, C.; Verzera, A. Flavour profile of capers (Capparis spinosa L.) from the Eolian Archipelago by HS-SPME/GC-MS. Food Chemistry 2007, 101, 1272-1278.

(7) Boti, J. B.; Koukoua, G.; N'Guessan, T. Y.; Muselli, A.; Bernardini, A.-F.; Casanova, J. Composition of the leaf, stem bark and root bark oils of Isolona cooperi investigated by GC (retention index), GC-MS and ${ }^{13} \mathrm{C}-\mathrm{NMR}$ spectroscopy. Phytochem. Anal. 2005, 16, 357-363.

(8) Gränicher, F.; Christen, P.; Kapetanidis, I. Essential oils from normal and hairy roots of Valeriana officinalis var. sambucifolia. Phytochemistry 1995, 40, 1421-1424.

(9) Flamini, G.; Tebano, M.; Cioni, P. L.; Bagci, Y.; Dural, H.; Ertugrul, K.; Uysal, T.; Savran, A. A multivariate statistical approach to Centaurea classification using essential oil composition data of some species from Turkey. Pl. Syst. Evol. 2006, 261, 217-228.

(10) Pinto, E.; Pina-Vaz, C.; Salgueiro, L.; Gonçalves, M. J.; Costa-de-Oliveira, S.; Cavaleiro, C.; Palmeira, A.; Rodrigues, A.; Martinez-deOliveira, J. Antifungal activity of the essential oil of Thymus pulegioides on Candida, Aspergillus and dermatophyte species. J. Med. Microbiol. 2006, 55, 1367-1373.

(11) Couladis, M.; Tzakou, O.; Stojanovic, D.; Mimica-Dukic, N.; Jancic, R. The essential oil composition of Salvia argentea L. Flavour Fragr. J. 2001, 16, 227-229.

(12) Gonny, M.; Cavaleiro, C.; Salgueiro, L.; Casanova, J. Analysis of Juniperus communis subsp. alpina needle, berry, wood and root oils by combination of GC, GC/MS and ${ }^{13}$ C-NMR. Flavour Fragr. J. 2006, 21, 99-106.

(13) Couladis, M.; Baziou, P.; Petrakis, P. V.; Harvala, C. Essential oil composition of Hypericum perfoliatum L. growing in different locations in Greece. Flavour Fragr. J. 2001, 16, 204-206.

(14) Boti, J. B.; Koukoua, G.; N'Guessan, T. Y.; Casanova, J. Chemical variability of Conyza sumatrensis and Microglossa pyrifolia from Côte d'Ivoire. Flavour Fragr. J. 2007, 22, 27-31.

(15) Lota, M.-L.; de Rocca Serra, D.; Tomi, F.; Bessiere, J.-M.; Casanova, J. Chemical composition of peel and leaf essential oils of Citrus medica L. and C. limonimedica Lush. Flavour Fragr. J. 1999, 14, 161-166.

(16) Blanc, M.-C.; Bradesi, P.; Gonçalves, M. J.; Salgueiro, L.; Casanova, J. Essential oil of Dittrichia viscosa ssp. viscosa: analysis by ${ }^{13}$ C-NMR and antimicrobial activity. Flavour Fragr. J. 2006, 21, 324-332.

(17) Ledauphin, J.; Saint-Clair, J.-F.; Lablanquie, O.; Guichard, H.; Founier, N.; Guichard, E.; Barillier, D. Identification of Trace Volatile Compounds in Freshly Distilled Calvados and Cognac Using Preparative Separations Coupled with Gas Chromatography-Mass Spectrometry. J. Agric. Food Chem. 2004, 52, 5124-5134.

(18) Bader, A.; Caponi, C.; Cioni, P. L.; Flamini, G.; Morelli, I. Composition of the essential oil of Ballota undulata, B. nigra ssp. foetida and B. saxatilis. Flavour Fragr. J. 2003, 18, 502-504.

(19) Babushok, V. I.; Linstrom, P. J.; Zenkevich, I. G. Retention Indices for Frequently Reported Compounds of Plant Essential Oils. J. Phys. Chem. Ref. Data 2011, 40, 043101-1-043101-47. 